\title{
Evaluation of Nutrients and Trace Metals and Their Enrichment Factors in Soil and Sugarcane Crop Irrigated with Wastewater
}

\author{
Mohammed Abdullah Alghobar, Sidduraiah Suresha* \\ Department of Environmental Science, Yuvaraja's College, University of Mysore, Mysore, India \\ Email: sureshakumar12@yahoo.com, alghobar@yahoo.com
}

Received 10 September 2015; accepted 13 October 2015; published 16 October 2015

Copyright (C) 2015 by authors and Scientific Research Publishing Inc.

This work is licensed under the Creative Commons Attribution International License (CC BY). http://creativecommons.org/licenses/by/4.0/

(c) (i) Open Access

\begin{abstract}
The study was conducted to investigate enrichment factor of wastewater (WW) irrigation to agricultural soils and the bioconcentration factor of trace metals uptake by sugarcane and to determine the concentrations of nutrients in sugarcane by growing the same on a contaminated soil, during the growth period of crop in Vidyaranyapuram area in the South West of Mysore, Karnataka. The concentrations of macronutrients and trace metals in the soil sampled sugarcane crop were found highly significant in $\mathrm{Ca}, \mathrm{Mg}, \mathrm{K}, \mathrm{Na}, \mathrm{N}, \mathrm{Mn}, \mathrm{Cu}, \mathrm{Ni}$ and $\mathrm{Cr}$. The enrichment factor was maximum for $\mathrm{N}$ and $\mathrm{Na}$, and the values of $\mathrm{N}$ and $\mathrm{Na}$ were in the significant enrichment category. Whereas the values of following elements ( $\mathrm{K}, \mathrm{P}, \mathrm{Ca}, \mathrm{SO}_{4}, \mathrm{Cu}, \mathrm{Cr}, \mathrm{Mg}, \mathrm{Mn}, \mathrm{Ni}, \mathrm{Cd}, \mathrm{Fe}, \mathrm{Pb}, \mathrm{Cl}, \mathrm{Co}$ and $\mathrm{Zn}$ ) in soil irrigated with $W W$ were in moderate enrichment category. The mean concentrations of $N, P$, $\mathrm{K}, \mathrm{Ca}, \mathrm{Na}, \mathrm{Fe}, \mathrm{Mn}$, and $\mathrm{Pb}$ in sugarcane leaves in wastewater treatment crops were significantly higher than those with ground water (GW) treated which showed the lowest concentrations. Calculation of the bioconcentration factor (BCF) indicated that the accumulation of heavy metals in sugarcane crop was in the order $\mathrm{Cd}>\mathrm{Zn}>\mathrm{Co}>\mathrm{Pb}>\mathrm{Mn}>\mathrm{Ni}>\mathrm{Cu}>\mathrm{Cr}>\mathrm{Fe}$. Pearson's correlation coefficient indicated the relationship between different elements content in soil and plant. The results showed that the elements, $\mathrm{Ca}, \mathrm{Mg}, \mathrm{Na}, \mathrm{K}, \mathrm{N}, \mathrm{P}, \mathrm{Mn}, \mathrm{Zn}$ and $\mathrm{Cr}$, were significantly positively correlated, between the soil and the plant.
\end{abstract}

\section{Keywords}

Heavy Metals, Wastewater, Sugarcane, Enrichment Factor

\footnotetext{
${ }^{*}$ Corresponding author.
}

How to cite this paper: Alghobar, M.A. and Suresha, S. (2015) Evaluation of Nutrients and Trace Metals and Their Enrichment Factors in Soil and Sugarcane Crop Irrigated with Wastewater. Journal of Geoscience and Environment Protection, 3, 46-56. http://dx.doi.org/10.4236/gep.2015.38005 


\section{Introduction}

There is increasing use of treated and untreated sewage water for irrigation, especially in the agricultural regions of India, and there is need to adequately assess the possible environmental impacts of such applications and agricultural practices, to ensure sustainable agricultural development. There is the possibility toxic of effects of trace elements in soil and their bioaccumulation in plants and vertical leaching/transport into shallow groundwater systems [1]. Irrigation with contaminated water contributes as a source of contamination of trace elements in agricultural soils and is harmful especially for vegetable production [2]. In agricultural soils, the presence of metals is of increasing concern because they have the potential to get accumulated in less soluble forms, get transferred into soil solution, and subsequently deteriorate the groundwater and crop quality [3]. Increasing soil heavy metal concentrations may result in increased uptake by plants and potentially cause serious health problems such as stomach ache, renal dysfunction and pulmonary emphysema [4]. Trace metal mobility depends on soil characteristics including soil $\mathrm{pH}$ and texture, the type and quantity of the oxyhydroxides present, the content of organic matter, and soil main constituents such as carbonates, phosphates, and clays which are responsible for toxic metal and metalloid sorption [5]. Increase of $\mathrm{pH}, \mathrm{EC}$ and availability of $\mathrm{N}, \mathrm{P}, \mathrm{K}, \mathrm{Fe}, \mathrm{Mn}, \mathrm{Zn}, \mathrm{Cu}, \mathrm{Cd}, \mathrm{Co}$, $\mathrm{Pb}, \mathrm{Ni}$ and $\mathrm{Cr}$ in surface layer of paper industry effluent irrigated soil, when compared to well water irrigated soils [6]. Mean concentrations of $\mathrm{Cu}, \mathrm{Fe}$, and $\mathrm{Cd}$ in irrigation water and $\mathrm{Cd}$ content in soil were much above the recommended levels. Accumulation of heavy metals in vegetables studied was lower than the recommended maximum tolerable levels proposed by the Joint FAO, with the exception of Cd which exhibited elevated level. Uptake and translocation pattern of metals from soil to edible parts of vegetables were quite distinguishable for almost all the elements examined [7]. Effect of irrigation of forage crops with treated sewage water provided factors other than $\mathrm{N}$ and $\mathrm{P}$ for improving crop production such as improving soil fertility and soil organic matter [8]. Soils irrigated with wastewater accumulated heavy metals like $\mathrm{Zn}, \mathrm{Pb}, \mathrm{Cd}, \mathrm{Ni}$ and $\mathrm{Cr}$ in surface soil [9]. Sewage water irrigated soils showed higher $\mathrm{Cd}$, $\mathrm{Ni}$ and $\mathrm{Cu}$ levels than the desirable levels, while the levels of $\mathrm{Hg}, \mathrm{Pb}$, and $\mathrm{Zn}$ were lower than the maximum threshold values recommended for crop production. Comparing between the crops, it was found that $\mathrm{Hg}$ and Cd levels were highest in soils under maize and declined linearly from maize to spinach to olive to tomato and control site [10]. Long term irrigation with sewage water led to the deposition of heavy metals $(\mathrm{Ni}, \mathrm{Pb}, \mathrm{Cd}, \mathrm{Cr}$ and $\mathrm{Cu}$ ) in soil and also bio-accumulation in the plants and tubers of potato crop [11]. Continuous use of sewage and industrial effluents for irrigation recorded improvement in water retention, hydraulic conductivity, organic C and build-up of available N, P, K and micronutrient status. The EC although increased due to sewage irrigation, it was within the tolerance limit to cause any soil salinity hazard. The toxic metals like $\mathrm{Cd}, \mathrm{Cr}$ and $\mathrm{Ni}$ were found to get accumulated in the soil and plant due to long-term use of sewage irrigation. Hence, $\mathrm{Cd}, \mathrm{Cr}$ and $\mathrm{Ni}$ are more likely to be the elements that may become health hazard for consumers of the crops grown in sewage irrigated soils. The concentrations of these metals were greater in leafy vegetables than in grain crops [12]. Understanding and prediction of the accumulation of heavy metals and metalloids in crops grown on contaminated croplands were motivated to secure crop quality and food safety [13]. The present study was conducted to investigate enrichment factor of sewage water irrigation to agricultural soils and the bioconcentration factor of trace metals uptake by sugarcane and to determine the concentrations of nutrients in sugarcane by growing the same on a contaminated soil.

\section{Materials and Methods}

\subsection{Description of Study Area}

The study area is located in the suburban area in the south western part of Mysore city, Karnataka, India, near Vidyaranyapuram sewage treatment plant. Locations were selected to gain understanding of the effect that typical wastewater (WW) creates on soil and sugarcane crop in Mysore city. The present study also covers the physico-chemical characteristics of water samples collected from Vidyaranyapuram sewage treatment plant station. More than fifty percent of the wastewater handled by in Mysore city is received by Vidyaranyapuram sewage treatment plant. The total sewage generation of sewage treatment plant is 67.75 million liters per day. It is a biological treatment plant situated next to the solid waste disposal area at the foothills of Chamundi Hills; the treated wastewater of Vidyaranyapuram sewage treatment plant crosses the Dalvai Lake and reaches drinking water source that is the Kabini River. The treated sewage water is pumped out after sewage treatment to field channels for direct use as irrigation water; also the farmers use this untreated wastewater for irrigating various 
crops.

\subsection{Sampling and Analysis of Water}

Wastewater (WW), treated wastewater (TWW) and ground water (GW) samples. Manual sampled water was carried collected in plastic bottles of $2000 \mathrm{ml}$ capacity which were thoroughly cleaned and were rinsed with the water being sampled. The randomly collected water samples were studied and analyzed for the physicochemical parameters in accordance with procedures outlined in Standard Methods (APHA) [14]. To estimate heavy metals concentration an aliquot consisting of $500 \mathrm{~mL}$ of water samples, ach digest was made up to $50 \mathrm{ml}$ with the addition of double distilled water. $\mathrm{Pb}, \mathrm{Zn}, \mathrm{Cu}, \mathrm{Co}, \mathrm{Cr}, \mathrm{Cd}, \mathrm{Fe}, \mathrm{Mn}$ and Ni were determined in the digest by ICP-OES (Perkin Elemer model 8000 DV).

\subsection{Soil Sampling and Analysis}

The survey was conducted around Vidyaranyapuram sewage treatment plant area of Mysore city during 20122013. In these areas wastewater both (treated and untreated) are being used by farmers for irrigation of sugarcane crop. Soil samples were routinely collected from fields to obtain a representative soil sample. In the fields, soil samples were collected from three depths (0 - 20, 20 - 40 and $40-60 \mathrm{~cm}$ ), by using auger of $3 \mathrm{~cm}$ diameter. Soil samples from the farmer's fields were randomly collected and bulked together to form a composite sample and transported to the laboratory. Samples were air-dried, crushed, passed through 2 mm sieve and saved in plastic bottles. Soil samples were analyzed as per the standard procedures of APHA [14] and ISI [15].

\subsection{Crop Sampling and Analysis}

Sugarcane crop samples were collected randomly in triplicate from fields irrigated with WW, as well as GW. In the laboratory, sugarcane leaves were washed with distilled water to remove soil particles, were dried in a hot air oven at $70^{\circ} \mathrm{C}-80^{\circ} \mathrm{C}$ for $24 \mathrm{~h}$, crushed and powdered for metals determination. For the digestion of sugarcane leaves samples, wet digestion method was used. For each analysis $0.5 \mathrm{~g}$ of the sample was accurately weighed and digested with $1 \mathrm{ml}$ of perchloric acid $\left(\mathrm{HClO}_{4}\right)$ and $4 \mathrm{ml}$ of Nitric acid $\left(\mathrm{HNO}_{3}\right)$. The samples were allowed to cool and the contents were filtered off using Whatman No. 42 filter paper. The filtrate was made up to $25 \mathrm{ml}$ with distilled water. Blank solution was made using the same procedure except the addition of leaf sample. Heavy metals (Fe, Mn, Cu, Zn, Pb, Cd, Ni, Co and Cr) concentrations in crop samples were estimated on ICPOES (Perkin Elmer, Model 8000 DV).

\section{Evaluation Indices and Data Analyses}

\subsection{Enrichment Factor (EF)}

EF is the relative abundance of a chemical element in a soil compared with the background [16]. In this study, the EF method was used to estimate the level of possible contamination of the soil. Elements accumulation in soil amended with wastewater on a contaminated site with respect to soil on uncontaminated soil (control soil) gives the EF. The EF is calculated according to the following equation [17]:

$\mathrm{EF}=$ concentration of metals in the amended soil/concentration of metals in the control soil

The enrichment factor is used to assess soil contamination (enrichment), and its interpretation is as follows: EF $<2$ - depletion to minimal enrichment, EF $2<5$ - Moderate enrichment, EF $5<20$ - Significant enrichment, EF $20<40$ - very high enrichment EF $>40$ - extremely high enrichment [18] [19]. EF can also be used to evaluate element depletion from soil [20].

\subsection{Bioconcentration Factor (BCF)}

BCF is a parameter used to describe the transfer of trace elements from soil to plants. It was calculated as the ratio between the concentration of particular elements in the plant and the same in the corresponding soil as well; all based on (dry weight) and for each crop calculated separately [21]. The BCF of Ca, Mg, Na, K, N, P, Fe, Mn, $\mathrm{Cu}, \mathrm{Zn}, \mathrm{Cd}, \mathrm{Ni}, \mathrm{Pb}, \mathrm{Co}$, and $\mathrm{Cr}$ and $\mathrm{Pb}$ in the plant samples were calculated as follows:

$\mathrm{BCF}=$ Concentration of heavy metal in plant/Concentration of heavy metal in soil 


\subsection{Statistical Analyses}

The results of soil and crop analyses were subjected to analyses of variance (ANOVA) as applicable to a completely randomized block design .The statistical analyses were performed for each parameter, and were compared as for Duncan's least significant difference test at $\mathrm{p}<0.05$. All statistical analyses were carried out using the SAS program, Version 9.1 [22]. Pearson's correlation coefficients between soil elements and elements in crops were calculated to evaluate the relation between these parameters in the soil and the crop. Correlation analysis was computed using the software package SPSS (version 19.0).

\section{Results and Discussion}

\subsection{Physical and Chemical Parameters of Wastewater Effluent}

The results of this study showed that the levels of pH were 7.50, 8.13, 9.19 and 8.30 in WW, TWW and GW, respectively. Generally WW treatment shows the lowest value. Domestic wastewater before treatment typically has a pH of 6.5 to 8.5, according to FAO [23]. Electrical conductivity of water is a useful and easy indicator of its salinity or total salt content. The conductivity values were 1032, 1225, 906 and $1099 \mu \mathrm{S} / \mathrm{cm}$, for WW, TWW and GW, respectively. The conductivity of water is useful as an indicator of the salinity or total salt content which is high in the wastewater. This result is in consistent with [24], who observed wastewater from domestic sewage often contained high amounts of dissolved salts. The concentration of TDS is 560, 624 and 696 for WW, TWW, and GW respectively. These values obtained for TDS for all the water samples were saline for irrigation waters purpose but lower than FAO [23] standard according to which it is $2000 \mathrm{mg} / \mathrm{l}$ for water samples for irrigation. So when used this type of water, do not use the more saline waters in this class on soils with restricted drainage. Even with adequate drainage, best management practice for salinity may be required, and the salt tolerance of the plants to be irrigated also must be considered [25]. The concentrations of COD for WW, TWW, and GW, were 964, 145 and $16 \mathrm{mg} / \mathrm{l}$, respectively. COD value is greater than that prescribed by FAO as shown in Table 1. in all different wastewaters. TDS cause toxicity through increased salinity, changes in the ionic composition of the water and toxicity of individual ions thereby resulting in low COD removal efficiencies [26]. While concentration of BOD in WW as higher than that of FAO values of $100 \mathrm{mg} / \mathrm{l}$. High COD and BOD concentration observed in the wastewater might be due to the use of chemicals, which are organic or inorganic [24].

The results of concentration of major ions, macronutrients and micronutrient in water samples are presented in Table 2 and Figure 1. Cation concentrations are within the permissible limit for irrigation water and anion concentrations of wastewater in all different water samples could be rated as marginal. Based on the results and on the standards given by FAO [23]-[27] for using the wastewater and for discharging them on land for irrigation it may be stated that the wastewater, is of less hazardous. Macro and Micronutrient status and the concentrations of heavy metals in are given in Figure 1. N and P concentrations of WW and TWW treatment are higher than permissible limits by FAO. The heavy metals (Fe, $\mathrm{Mn}, \mathrm{Cu}, \mathrm{Zn}, \mathrm{Cd}, \mathrm{Ni}, \mathrm{Pb}, \mathrm{Co}$, and $\mathrm{Cr}$ ) analysed in irrigation water are not at elevated levels except $\mathrm{Cd}$, which is higher in wastewater and groundwater (Figure 1). On average, the levels of $\mathrm{Mn}$ were higher in the irrigation water sources compared to the recommended $0.1 \mathrm{mg} / \mathrm{l}$; the concentration of $\mathrm{Cu}$ was below detection limits. Related studies on wastewater irrigation in two cities in India have shown similar trends. In Varanasi, [28] reported equally low levels in wastewater. Continuous application of irrigation from wastewater could contribute to heavy metal accumulation in soils and crops, even if their levels are low in irrigation water source.

\subsection{Effect of Wastewater Irrigation on Soil Properties}

Soil properties greatly influence the availability of nutrients and elements to plants [29]. The solubility of metallic

Table 1. Physiochemical parameters of water samples.

\begin{tabular}{cccccccc}
\hline Water quality & $\mathrm{T}^{\circ} \mathrm{C}$ & $\mathrm{pH}$ & $\mathrm{EC} \mu \mathrm{s} / \mathrm{cm}$ & $\mathrm{DO} \mathrm{mg} \cdot \mathrm{L}^{-1}$ & $\mathrm{COD} \mathrm{mg} \cdot \mathrm{L}^{-1}$ & $\mathrm{BOD} \mathrm{mg} \cdot \mathrm{L}^{-1}$ & $\mathrm{TDS}_{\mathrm{mg} \cdot \mathrm{L}^{-1}}$ \\
\hline WW & 25 & 7.50 & 1032 & $\mathrm{Nil}$ & 964 & 560 \\
TWW & 25 & 8.13 & 1225 & 2.3 & 145 & 30 \\
GW & 25 & 8.30 & 1099 & 6.9 & 16 & 2 \\
Standard Limit for irrigation [23]-[27] & & $6.5-8.5$ & $<3000$ & $<9$ & $80-500$ & 100 \\
\hline
\end{tabular}


Table 2. Concentration of major ions $\left(\mathrm{mg} \cdot \mathrm{L}^{-1}\right)$ in different water samples.

\begin{tabular}{cccccccccc}
\hline \multirow{2}{*}{ Water quality } & \multicolumn{4}{c}{ Cation $\mathrm{mgL}^{-1}$} & \multicolumn{4}{c}{ Anion $\mathrm{mgL}^{-1}$} \\
\cline { 2 - 10 } & $\mathrm{Na}^{+}$ & $\mathrm{K}^{+}$ & $\mathrm{Ca}^{2+}$ & $\mathrm{Mg}^{2+}$ & $\mathrm{HCO}_{3}^{-}$ & $\mathrm{CO}_{3}^{2-}$ & $\mathrm{Cl}^{-}$ & $\mathrm{SO}_{4}^{2-}$ \\
WW & 48 & 24 & 43.37 & 27.01 & 296 & $\mathrm{Nil}$ & 93 & 24 \\
TWW & 60 & 20 & 62.64 & 28.89 & 392 & $\mathrm{Nil}$ & 115 & 20 \\
GW & 56 & 20 & 56.22 & 68.50 & 544 & 40 & 17 & 52 \\
Standard Limit for irrigation [23]-[27] & 900 & - & 400 & 60 & 600 & 6 & 1100 & 1000 \\
\hline
\end{tabular}

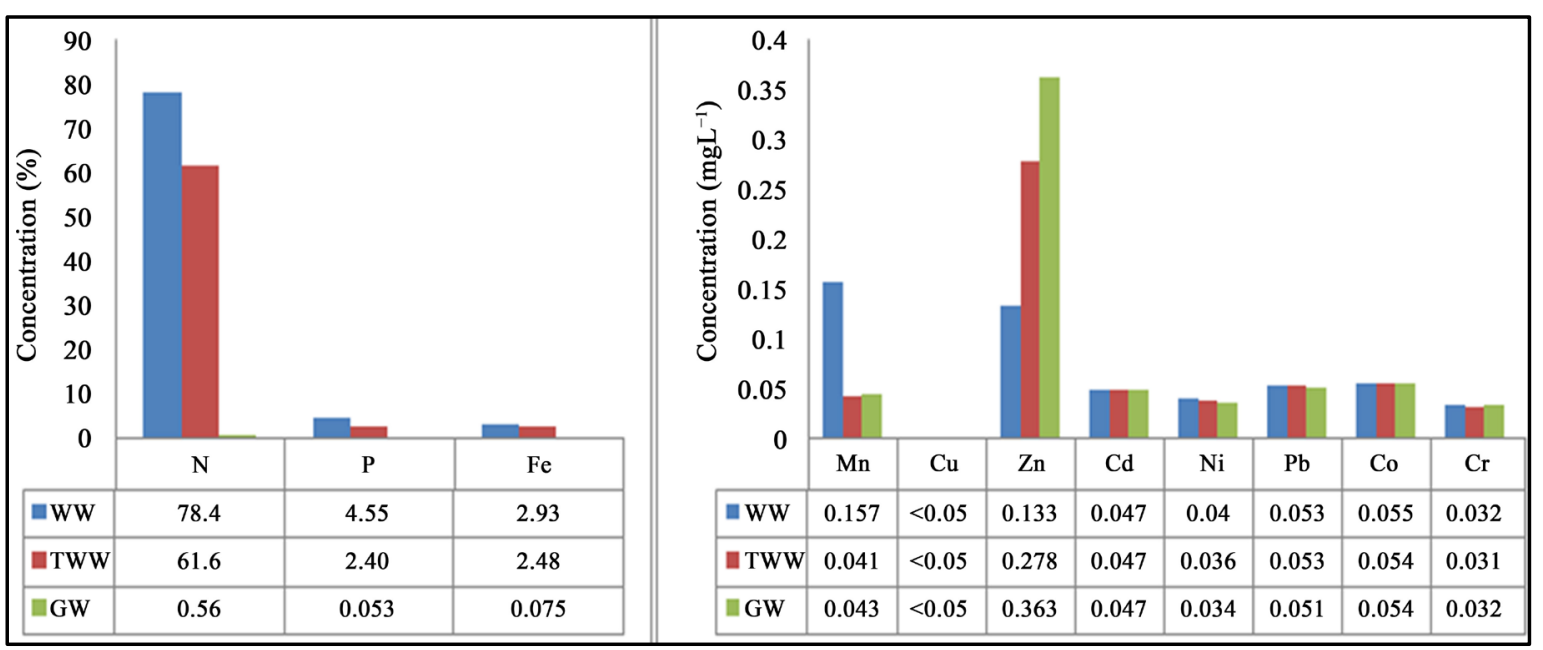

Figure 1. Concentration of macronutrients and micronutrient in water samples.

ions depends on various soil physiochemical factors, such as the $\mathrm{pH}$ [30]. In the present study, analysis of soils irrigated with different wastewater was performed to study the effect of soil properties on enrichment factor and availability of nutrients in soil. The data of soil analysis are shown in Table 3. Soils sampled with WW showed acidic $\mathrm{pH}$ against alkaline $\mathrm{pH}$ of TWW and GW soils, the values were 6.67 for WW, 7.56 and 7.92 respectively. Data presented in Table 3 also show that the soil EC of experimental field was significantly influenced by WW irrigation, which are 259 and $214 \mu \mathrm{s} / \mathrm{cm}$ for WW and TWW irrigated soil respectively. The exchangeable cations like Ca, Mg, K and Na showed highly significant difference between WW, TWW and GW, the mean value content recorded of WW, TWW and GW in the present study were $0.90 \%, 0.81 \%$ and $0.50 \%$ for Ca, $0.44 \%$, $0.39 \%$ and $0.34 \%$ for $\mathrm{Mg}, 0.31 \%, 0.22 \%$ and $0.059 \%$ for $\mathrm{Na}, 0.44 \%, 0.33 \%$ and $0.13 \%$ for $\mathrm{K}$. $\mathrm{N}$ content showed highly significant value of WW for $0.53 \%$ followed $0.46 \%$ for TWW and lowest of $0.038 \%$ was for GW. The low organic nitrogen content of the untreated olive mill wastewaters increased the soil $\mathrm{C} / \mathrm{N}$ ratio to as much as 50 [31]. In the case of P, the highly significant value was $0.061 \%$ for WW compared to lower value of $0.032 \%$ for control GW. The WW contained appreciable amounts of useful major plant nutrients, such as N, P, K, and $\mathrm{Ca}$, which are reflected in the appreciable build-up of these nutrients in the sewage-irrigated soils [32]. Soil concentrations of heavy metals were found highly significant values in the $\mathrm{Mn}, \mathrm{Cu}, \mathrm{Ni}$ and $\mathrm{Cr}$ in the field experiment soils due to the application of wastewater are given in Table 3. Heavy metal concentration in WW, TWW and GW irrigated sites ranged between 238, 224 and $204 \mathrm{mg} / \mathrm{kg}$ for Mn, 266, 243 and $177 \mathrm{mg} / \mathrm{kg}$ for Cu, 58, 54 and $51 \mathrm{mg} / \mathrm{kg}$ for $\mathrm{Ni}$ and 107, 99 and $80 \mathrm{mg} / \mathrm{kg}$ for Cr. According to [33] although the concentration of heavy metals in sewage effluents are low, long-term use of WW on agricultural lands often results in the buildup of elevated levels of heavy metals in soil. In WW irrigated soil $\mathrm{Mn}, \mathrm{Cu}, \mathrm{Ni}$ and $\mathrm{Cr}$ contents were significant high $\mathrm{Fe}, \mathrm{Cd}, \mathrm{Pb}$ and $\mathrm{Co}$ were equal and $\mathrm{Zn}$ was lower on compared to GW irrigated soil.

\subsection{Assessment of Trace Metals Enrichment Factor (EF) in Soils}

Enrichment factor is an indication of the anthropogenic impact on soil or enrichment factor can give an insight into differentiating an anthropogenic source from a natural origin [34]. The enrichment factor of the elements in 
Table 3. Nutrients concentrations and estimated enrichment factors for soil.

\begin{tabular}{|c|c|c|c|c|c|}
\hline \multirow{2}{*}{ Parameters } & \multicolumn{2}{|c|}{ Soil of WW } & \multicolumn{2}{|c|}{ Soil of TWW } & \multirow{2}{*}{ Soil of GW (Control) } \\
\hline & Treatment & $\mathrm{EF}$ & Treatment & $\mathrm{EF}$ & \\
\hline $\mathrm{pH}$ & $6.67 \mathrm{c}$ & - & $7.56 \mathrm{~b}$ & - & $7.92 \mathrm{a}$ \\
\hline $\mathrm{EC} \mu \mathrm{s} / \mathrm{cm}$ & 259 a & - & $214 b$ & - & $187 \mathrm{c}$ \\
\hline $\mathrm{Ca}^{2+} \%$ & $0.90 \mathrm{a}$ & 1.80 & $0.81 \mathrm{ab}$ & 1.60 & $0.50 \mathrm{c}$ \\
\hline $\mathrm{Mg}^{2+} \%$ & $0.44 \mathrm{a}$ & 1.30 & $0.39 \mathrm{ab}$ & 1.15 & $0.34 \mathrm{~b}$ \\
\hline $\mathrm{Na}^{+} \%$ & $0.31 \mathrm{a}$ & 5.25 & $0.22 \mathrm{~b}$ & 3.72 & $0.059 \mathrm{c}$ \\
\hline $\mathrm{K}^{+} \%$ & $0.44 \mathrm{a}$ & 3.38 & $0.33 \mathrm{~b}$ & 2.54 & $0.13 \mathrm{c}$ \\
\hline $\mathrm{Cl}^{-} \%$ & $0.002 \mathrm{a}$ & 1.00 & $0.002 \mathrm{a}$ & 1.00 & $0.002 \mathrm{a}$ \\
\hline $\mathrm{N} \%$ & $0.53 \mathrm{a}$ & 13.95 & $0.46 \mathrm{a}$ & 12.11 & $0.038 \mathrm{~b}$ \\
\hline $\mathrm{P} \%$ & $0.061 \mathrm{a}$ & 1.97 & $0.041 \mathrm{~b}$ & 1.28 & $0.032 \mathrm{~b}$ \\
\hline $\mathrm{SO}_{4}^{2-} \%$ & 0.0017 a & 1.70 & 0.0017 a & 1.07 & $0.0010 \mathrm{a}$ \\
\hline $\mathrm{Fe}^{2+} \%$ & $3.63 \mathrm{a}$ & 1.02 & $3.53 \mathrm{a}$ & 0.99 & $3.55 \mathrm{a}$ \\
\hline $\mathrm{Mn}^{2+} \mathrm{mg} / \mathrm{kg}$ & 238 a & 1.16 & $224 \mathrm{~b}$ & 1.09 & $204 \mathrm{c}$ \\
\hline $\mathrm{Cu}^{2+} \mathrm{mg} / \mathrm{kg}$ & 266 a & 1.50 & $243 \mathrm{~b}$ & 1.37 & $177 \mathrm{~d}$ \\
\hline $\mathrm{Zn}^{2+} \mathrm{mg} / \mathrm{kg}$ & $341 \mathrm{~d}$ & 0.67 & $404 \mathrm{c}$ & 0.80 & $503 \mathrm{a}$ \\
\hline $\mathrm{Cd}^{2+} \mathrm{mg} / \mathrm{kg}$ & $12 \mathrm{a}$ & 1.09 & $12 \mathrm{a}$ & 1.09 & $11 \mathrm{a}$ \\
\hline $\mathrm{Ni}^{2+} \mathrm{mg} / \mathrm{kg}$ & $58 \mathrm{a}$ & 1.13 & $54 \mathrm{~b}$ & 1.05 & $51 \mathrm{~b}$ \\
\hline $\mathrm{Pb}^{2+} \mathrm{mg} / \mathrm{kg}$ & $81 \mathrm{a}$ & 1.02 & $80 \mathrm{a}$ & 1.01 & 79 a \\
\hline $\mathrm{Co}^{2+} \mathrm{mg} / \mathrm{kg}$ & $16 \mathrm{a}$ & 1.00 & $16 \mathrm{a}$ & 1.00 & $16 \mathrm{a}$ \\
\hline $\mathrm{Cr}^{2+} \mathrm{mg} / \mathrm{kg}$ & 107 a & 1.34 & $99 \mathrm{~b}$ & 1.24 & $80 \mathrm{~d}$ \\
\hline
\end{tabular}

Different letters in the same row indicate significant difference among means as determined by Duncan’s multiple-range test (p $<0.05$ ).

soil were in the sequence of $\mathrm{N}(13.95)>\mathrm{Na}(5.25)>\mathrm{K}(3.83)>\mathrm{P}(1.97)>\mathrm{Ca}(1.80)>\mathrm{SO}_{4}(1.70)>\mathrm{Cu}(1.50)>$ $\mathrm{Cr}(1.34)>\mathrm{Mg}(1.30)>\mathrm{Mn}(1.16)>\mathrm{Ni}(1.13)>\mathrm{Cd}(1.09)>\mathrm{Fe}, \mathrm{Pb}(1.02)>\mathrm{Cl}$, Co (1.00) $>\mathrm{Zn}(0.67)$ in the WW irrigated soil (Table 3). However, values of $\mathrm{N}$ and $\mathrm{Na}$ were in the enrichment categories of significant enrichment, while values of $\mathrm{K}, \mathrm{P}, \mathrm{Ca}, \mathrm{SO}_{4}, \mathrm{Cu}, \mathrm{Cr}, \mathrm{Mg}, \mathrm{Mn}, \mathrm{Ni}, \mathrm{Cd}, \mathrm{Fe}, \mathrm{Pb}, \mathrm{Cl}, \mathrm{Co}$ and $\mathrm{Zn}$ in the enrichment categories of moderate enrichment. The EF values of elements in soil irrigated with TWW was in the order $\mathrm{N}$ $(12.11)>\mathrm{Na}(3.72)>\mathrm{K}(2.54)>\mathrm{Ca}(1.60)>\mathrm{Cu}(1.37)>\mathrm{P}(1.28)>\mathrm{Cr}(1.24)>\mathrm{Mg}(1.15)>\mathrm{Mn}, \mathrm{Cd}(1.09)>$ $\mathrm{SO}_{4}(1.07)>\mathrm{Ni}(1.05)>\mathrm{Pb}(1.01)>\mathrm{Cl}$, Co (1.00) $>\mathrm{Fe}(0.99)>\mathrm{Zn}(0.80)$. There are significant differences in enrichment factor values among the elements; value of $\mathrm{N}$ is in the enrichment category of significant enrichment. While values of $\mathrm{Na}, \mathrm{K}, \mathrm{Ca}, \mathrm{Cu}, \mathrm{P}, \mathrm{Cr}, \mathrm{Mg}, \mathrm{Mn}, \mathrm{Cd}, \mathrm{SO}_{4}, \mathrm{Ni}, \mathrm{Pb}, \mathrm{Cl}, \mathrm{Co}, \mathrm{Fe}$ and $\mathrm{Zn}$ are in the moderate enrichment category. When enrichment value is high $(>1)$ it indicates higher availability and distribution of metals in soil irrigated with contaminated water and thereby increasing the average heavy metal concentration in major crops, vegetables and weeds in wastewater irrigated area with respect to their reference values [35]. [36] reported the enrichment factor values were lower than the values of heavy metals in soil irrigated with wastewater generated from the sponge iron industries which were in the moderate enrichment category.

\subsection{Nutrient Concentrations in Plants}

Mean concentrations of macronutrients, and heavy metals in sugarcane leaves are presented in Table 4. Higher concentrations of macronutrients $(\mathrm{N}, \mathrm{P}, \mathrm{K}, \mathrm{Ca}$, and $\mathrm{Na}$ ) in plants were observed in treatment irrigated with wastewater; the constant trend in their concentrations in decreasing order was as follows: WW, TWW, and GW, The mean values were $1.94 \%, 1.84 \%$ and $0.46 \%$, for $\mathrm{N}, 0.16 \%, 0.13 \%$ and $0.10 \%$ for $\mathrm{P}, 1.25 \%, 1.18 \%$ and $0.93 \%$ for $\mathrm{K}, 0.64 \%, 0.63 \%$ and $0.51 \%$ for $\mathrm{Ca}, 0.27 \%, 0.25 \%$ and $0.24 \%$ for $\mathrm{Na}$. Irrigation with raw or diluted wastewater resulted in higher concentrations of most nutrients in the millet plant tissues, as expected, this higher accumulation in plant paralleled higher nutrient concentrations in the irrigation water [37]. 
Table 4. Mean concentrations of macronutrients and heavy metals in sugarcane leaves.

\begin{tabular}{cccc}
\hline Parameters & WW & TWW & GW \\
\hline $\mathrm{Ca}^{2+} \%$ & $0.64 \mathrm{a}$ & $0.63 \mathrm{ab}$ & $0.51 \mathrm{c}$ \\
$\mathrm{Mg}^{2+} \%$ & $0.34 \mathrm{a}$ & $0.37 \mathrm{a}$ & $0.39 \mathrm{a}$ \\
$\mathrm{Na}^{+} \%$ & $0.27 \mathrm{a}$ & $0.25 \mathrm{~b}$ & $0.24 \mathrm{~b}$ \\
$\mathrm{~K}^{+} \%$ & $1.25 \mathrm{a}$ & $1.18 \mathrm{a}$ & $0.93 \mathrm{~b}$ \\
$\mathrm{~N} \%$ & $1.94 \mathrm{a}$ & $1.84 \mathrm{a}$ & $0.46 \mathrm{c}$ \\
$\mathrm{P} \%$ & $0.16 \mathrm{a}$ & $0.13 \mathrm{~b}$ & $0.10 \mathrm{c}$ \\
$\mathrm{Fe}^{2+} \mathrm{mg} / \mathrm{kg}$ & $410 \mathrm{a}$ & $370 \mathrm{~b}$ \\
$\mathrm{Mn}^{2+} \mathrm{mg} / \mathrm{kg}$ & $72 \mathrm{a}$ & $66 \mathrm{~b}$ & $58 \mathrm{c}$ \\
$\mathrm{Cu}^{2+} \mathrm{mg} / \mathrm{kg}$ & $38 \mathrm{a}$ & $36 \mathrm{a}$ & $35 \mathrm{a}$ \\
$\mathrm{Zn}^{2+} \mathrm{mg} / \mathrm{kg}$ & $220 \mathrm{c}$ & $332 \mathrm{a}$ \\
$\mathrm{Cd}^{2+} \mathrm{mg} / \mathrm{kg}$ & $13 \mathrm{a}$ & $283 \mathrm{~b}$ & $13 \mathrm{a}$ \\
$\mathrm{Ni}^{2+} \mathrm{mg} / \mathrm{kg}$ & $12 \mathrm{a}$ & $13 \mathrm{a}$ & $11 \mathrm{a}$ \\
$\mathrm{Pb}^{2+} \mathrm{mg} / \mathrm{kg}$ & $30 \mathrm{a}$ & $12 \mathrm{a}$ & $25 \mathrm{~b}$ \\
$\mathrm{Co}^{2+} \mathrm{mg} / \mathrm{kg}$ & $8 \mathrm{a}$ & $27 \mathrm{ab}$ & $8 \mathrm{a}$ \\
$\mathrm{Cr}^{2+} \mathrm{mg} / \mathrm{kg}$ & $15 \mathrm{a}$ & $14 \mathrm{a}$ & $13 \mathrm{a}$ \\
\hline
\end{tabular}

Different letters in the same row indicate significant difference among means as determined by Duncan’s multiple-range test $(\mathrm{p}<0.05)$.

Table 5. Bioconcentration factors for heavy metals in sugarcane crop.

\begin{tabular}{llcc}
\hline Parameters & WW & TWW & GW \\
\hline $\mathrm{Fe}^{2+} \mathrm{mg} / \mathrm{kg}$ & 0.01 & 0.01 & 0.01 \\
$\mathrm{Mn}^{2+} \mathrm{mg} / \mathrm{kg}$ & 0.30 & 0.29 & 0.28 \\
$\mathrm{Cu}^{2+} \mathrm{mg} / \mathrm{kg}$ & 0.14 & 0.14 & 0.19 \\
$\mathrm{Zn}^{2+} \mathrm{mg} / \mathrm{kg}$ & 0.64 & 0.70 & 0.66 \\
$\mathrm{Cd}^{2+} \mathrm{mg} / \mathrm{kg}$ & 1.08 & 1.08 & 1.18 \\
$\mathrm{Ni}^{2+} \mathrm{mg} / \mathrm{kg}$ & 0.20 & 0.22 & 0.21 \\
$\mathrm{~Pb}^{2+} \mathrm{mg} / \mathrm{kg}$ & 0.37 & 0.33 & 0.35 \\
$\mathrm{Co}^{2+} \mathrm{mg} / \mathrm{kg}$ & 0.50 & 0.50 & 0.50 \\
$\mathrm{Cr}^{2+} \mathrm{mg} / \mathrm{kg}$ & 0.14 & 0.14 & 0.16 \\
\hline
\end{tabular}

Concentration of heavy metals $(\mathrm{Fe}, \mathrm{Mn}, \mathrm{Pb})$ in sugarcane leaves in $\mathrm{WW}$ treatments were significantly higher compared to GW treatments which had the lowest concentration. While the mean values for WW, TWW, and GW were 410, 370 and $340 \mathrm{mg} / \mathrm{kg}, 72,66$ and $58 \mathrm{mg} / \mathrm{kg}, 30,27$ and $25 \mathrm{mg} / \mathrm{kg}$ for Fe, Mn and Pb, respectively. This is in consistent with reports of higher concentration of heavy metals in vegetables from wastewater irrigated areas as compared to tube well water irrigated areas [38] [39] analyzed plants for $\mathrm{Cd}, \mathrm{Cr}, \mathrm{Ni}, \mathrm{Pb}, \mathrm{Co}, \mathrm{Zn}$, $\mathrm{Cu}, \mathrm{Fe}$ and $\mathrm{Mn}$ in sewage contaminated area. Plants grown on polluted soil irrigated with wastewater recorded higher level of heavy metals, although the levels of heavy metals in the wastewater are low, the irrigated soil shows much higher concentrations of heavy metals, this may be due to the accumulation of heavy metals in the soil due to long-term irrigation, this high concentration of heavy metals in soil irrigated with wastewater and thereby increasing the average heavy metal concentration in cultivated vegetables in wastewater-irrigated area with respect to their reference values.

\subsection{Bioconcentration Factor (BCF) for Heavy Metals in Sugarcane Crop}

Bioconcentration factors are shown in Table 5. It was calculated for elements transfer from soil to sugarcane. The Bioconcentration factors for elements in soil irrigated with WW were in the descending order of Cd (1.08) > $\mathrm{Zn}(0.64)>\mathrm{Co}(0.50)>\mathrm{Pb}(0.37)>\mathrm{Mn}(0.30)>\mathrm{Ni}(0.20)>\mathrm{Cu}$, Cr (0.14) Fe (0.01), for TWW the elements were $\mathrm{Cd}(1.08)>\mathrm{Ca}(0.77)>\mathrm{Zn}(0.70)>\mathrm{Co}(0.50)>\mathrm{Pb}(0.33)>\mathrm{Mn}(0.29)>\mathrm{Ni}(0.22)>\mathrm{Cu}, \mathrm{Cr}(0.14) \mathrm{Fe}(0.01)$, 


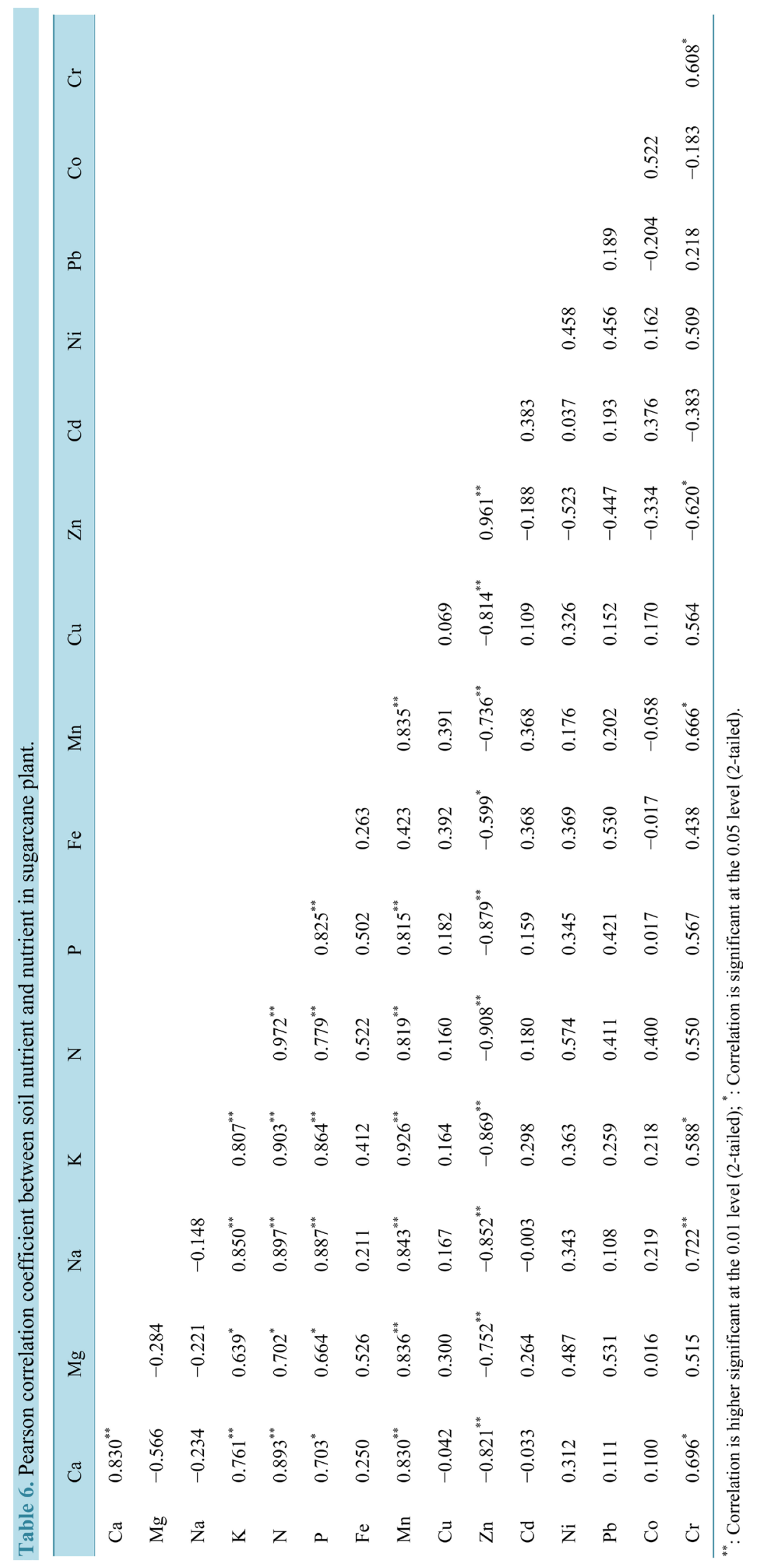


whereas in the control site GW, it was in the order of $\mathrm{Cd}(1.18)>\mathrm{Zn}(0.66)>\mathrm{Co}(0.50)>\mathrm{Pb}(0.35)>\mathrm{Mn}(0.28)>$ $\mathrm{Ni}(0.21)>\mathrm{Cu}(0.19)>\mathrm{Cr}(0.16) \mathrm{Fe}(0.01)$. There was no a significant difference in BCF values among the WW, TWW and GW sampling sites. Relatively high BCF values were found for $\mathrm{Mn}$ and $\mathrm{Pb}$ in $\mathrm{WW}$ site grown sugarcane crop, whereas the lowest BCF values were found for control site (GW). When BCF is $\leq 1$, this denotes that the plant only absorbs but does not accumulate heavy metals; when BCF $>1$, this indicates that plant accumulates metals [40]. Bioconcentration factor values of heavy metals were less than 1 in the sugarcane except for Cd which was $>1$. The results indicate that metal bioavailability was low at WW, TWW and control site (GW).

\subsection{Pearson's Correlation between Elements in Soil and Plant}

The relationship between different elements content in soil and plant were analyzed by Pearson's correlation coefficient. The correlation analysis is a bivariant method which is applied to describe the relation between two different parameters. The high correlation co-efficient (near +1 or -1 ) means a good relation between two variables, and its concentration around zero means no relationship between them at a significant level of $0.05 \%$ level, it is strongly correlated, if $r>0.7$, as where $r$ values between 0.5 and 0.7 show moderate correlation between two different parameters [41]. Pearson's correlation at 5\% and 1\% levels of significance was calculated for finding relationship between elements content in soil and plant. Significant positive correlation was observed between different elements in soil and plant suggesting the correlation of elements irrigated with wastewater (Table 6). The variation of elements content in soils was well correlated to plant. The results showed that the relationship among the elements $\mathrm{Ca}, \mathrm{Mg}, \mathrm{Na}, \mathrm{K}, \mathrm{N}, \mathrm{P}, \mathrm{Mn}, \mathrm{Zn}$ and $\mathrm{Cr}$, were significant correlations, between the soil and the plant, showed strong positive correlation; this may be due to their common source in the wastewater. While there were no correlations observed with $\mathrm{Fe}, \mathrm{Cu}, \mathrm{Cd}, \mathrm{Ni}, \mathrm{Pb}$ and $\mathrm{Co}$. The translocation of elements from soil to plant parts (transfer factor) was calculated to determine the relative uptake of heavy metals by the plants with respect to soil. The ratio of metals between soil and plant parts (TF) is an important criterion for the contamination assessment of soils with high level of heavy metals. The ratio " $>1$ " means higher accumulation of metals in plant parts than soil [42].

\section{Conclusion}

This study was carried out to assess the enrichment factor as a result of wastewater irrigation to agricultural soil and also the bioconcentration factor by trace metals uptake by sugarcane and to determine the concentrations of nutrients in sugarcane crop by growing on contaminated sites in Vidyaranyapuram area. The high manurial values in the form of macro nutrients like N, P, K, Ca and Mg were provided by wastewater, which is the effect on soils and also as an alternate source of water for agriculture, for the crops. However, the results of the study showed high significance for $\mathrm{Mn}, \mathrm{Cu}, \mathrm{Ni}$ and $\mathrm{Cr}$ contents in soil and $\mathrm{Fe}, \mathrm{Mn}, \mathrm{Zn}, \mathrm{Cu}, \mathrm{Pb}, \mathrm{Ni}, \mathrm{Cd}, \mathrm{Co}$ and $\mathrm{Cr}$ concentrations were highly significant in sugarcane tissue, which was the soil irrigated with wastewater continuously soil for 12 years. Generally, the average application rate of wastewater should not be in excess of the normally allowable application rates. Hence the wastewater should be used judiciously for irrigation purpose in agriculture.

\section{References}

[1] Cui, Y., Zhu, Y.G., Zhai, R., Huang, Y., Qiu, Y. and Liang, J. (2005) Exposure to Metal Mixtures and Human Health Impacts in a Contaminated Area in Nanning, China. Environment International, 31, 784-790. http://dx.doi.org/10.1016/j.envint.2005.05.025

[2] Huang, B., Shi, X., Yu, D., Oborn, I., Blomback, K., Pagella, T.F., Wang, H., Sun, W. and Sinclair, F.L. (2006) Environmental Assessment of Small-Scale Vegetable Farming Systems in Peri-Urban Areas of the Yangtze River Delta Region, China. Agriculture, Ecosystems and Environment, 112, 391-402. http://dx.doi.org/10.1016/j.agee.2005.08.037

[3] Kelepertzis, E. (2014) Accumulation of Heavy Metals in Agricultural Soils of Mediterranean: Insights from Argolida Basin, Peloponnese, Greece. Geoderma, 221-222, 82-90. http://dx.doi.org/10.1016/j.geoderma.2014.01.007

[4] Yeung, A. and Hsu, C. (2005) Electrokinetic Remediation of Cadmium Contaminated Clay. Journal of Environmental Engineering, 131, 298-304. http://dx.doi.org/10.1061/(ASCE)0733-9372(2005)131:2(298)

[5] Marcussen, H., Holm, P.E., Strobel, B.W. and Hansen, H.C.B. (2009) Nickel Sorption to Goethite and Montmorillonite in Presence of Citrate. Environmental Science and Technology, 43, 1122-1127. http://dx.doi.org/10.1021/es801970z 
[6] Roy, R., Prasad, J. and Joshi, A.P. (2008) Changes in Soil Properties Due to Irrigation with Paper Industry Wastewater. Journal of Environmental Science and Engineering, 50, 277-282.

[7] Ahmad, J.U. and Abdul Goni, M. (2010) Heavy Metal Contamination in Water, Soil, and Vegetables of the Industrial Areas in Dhaka, Bangladesh. Environmental Monitoring and Assessment, 166, 347-357. http://dx.doi.org/10.1007/s10661-009-1006-6

[8] Munir, J.M. and Ayadi, M. (2005) Forage Yield and Nutrient Uptake as Influenced by Secondary Treated Wastewater. Journal of Plant Nutrition, 27, 351-365. http://dx.doi.org/10.1081/PLN-120027659

[9] Mishra, V.K., Upadhyay, A.R. and Tripathi, B.D. (2009) Bioaccumulation of Heavy Metals and Two Organochlorine Pesticides (DDT and BHC) in Crops Irrigated with Secondary Treated Wastewater. Environment Monitoring and Assessment, 156, 99-107. http://dx.doi.org/10.1007/s10661-008-0466-4

[10] Dikinya, O. and Areola, O. (2010) Comparative Analysis of Heavy Metal Concentration in Secondary Treated Wastewater Irrigated Soils Cultivated by Different Crops. International Journal of Environmental Science and Technology, 7, 337-346. http://dx.doi.org/10.1007/BF03326143

[11] Bharose, R., Lal, B.S., Singh, K.S. and Srivastava, K.P. (2013) Heavy Metals Pollution in Soil-Water-Vegetation Continuum Irrigated with Ground Water and Untreated Sewage. Bulletin of Environmental and Scientific Research, 2, 1-8.

[12] Antil, R.S. (2012) Impact of Sewage and Industrial Effluents on Soil-Plant Health, Industrial Waste. InTech. http://www.intechopen.com/books/industrial-waste/impact-of-sewer-water-and-industrial-wastewaters-on-soilplant-hea lth

[13] Adamsa, M.L., Zhao, F.J., Mc Gratha, S.P., Nicholsonb, F.A. and Chambersb, B.J. (2004) Predicting Cadmium Concentrations in Wheat and Barley Grain Using Soil Properties. Journal of Environmental Quality, 33, 532-541. http://dx.doi.org/10.2134/jeq2004.5320

[14] APHA (1998) Standard Methods for Examination of Water and Wastewater. 20th Edition, American Public Health Association, Washington DC.

[15] Indian Standards (1982) Tolerance Limits for Inland Surface Water Subject to Pollution. IS: 2296-1082.

[16] Hernandez, L., Probst, A., Probst, J.L. and Ulrich, E. (2003) Heavy Metal Distribution in Some French Forest Soils: Evidence for Atmosphere Contamination. Science of the Total Environment, 312, 195-210. http://dx.doi.org/10.1016/S0048-9697(03)00223-7

[17] Al-Hwaiti, M. and Al-Khashman, O. (2015) Health Risk Assessment of Heavy Metals Contamination in Tomato and Green Pepper Plants Grown in Soils Amended with Phosphogypsum Waste Materials. Environmental Geochemistry and Health, 37, 287-304.

[18] Kartal, S., Aydın, Z. and Tokalığlu, S. (2006) Fractionation of Metals in Street Sediment Samples by Using the BCR Sequential Extraction Procedure and Multivariate Statistical Elucidation of the Data. Journal of Hazardous Materials, 132, 80-89. http://dx.doi.org/10.1016/j.jhazmat.2005.11.091

[19] Sutherland, R.A. (2000) Bed Sediment-Associated Trace Metals in an Urban Stream. Oahu, Huwaii, Environmental Geology, 39, 611-627. http://dx.doi.org/10.1007/s002540050473

[20] Blaser, P., Zimmermann, S., Luster, J. and Shoty, K.W. (2000) Critical Examination of Trace Element Enrichment and Depletions in Soils: As, Cr, Cu, Ni, Pb and Zn in Swiss Forest Soil. Science of the Total Environment, 249, 257-280. http://dx.doi.org/10.1016/S0048-9697(99)00522-7

[21] Liu, W., Li, X., Li, H.H. and Wang, Y.W. (2006) Heavy Metal Accumulation of Edible Vegetables Cultivated in Agricultural Soil in the Suburb of Zhengzhou City, People's Republic of China. Bulletin of Environmental Contamination and Toxicology, 76, 163-170. http://dx.doi.org/10.1007/s00128-005-0903-9

[22] SAS (2004) Statistical Analysis System. SAS Institute, Inc., Cary.

[23] FAO (1992) Wastewater Treatment and Use in Agriculture. Irrigation and Drainage Paper 47, FAO, Rome.

[24] Singh, S.N., Srivastav, G. and Bhatt, A. (2012) Physicochemical Determination of Pollutants in Wastewater in Dheradun. Current World Environment, 7, 133-138.

[25] Environment Protection Authority (1991) Guidelines for Wastewater Irrigation. Publication 168, Environment Protection Authority, Melbourne.

[26] Kargi, F. and Dincer, A.R. (1996) Effect of Salt Concentration on Biological Treatment of Saline Wastewater by FedBatch Operation. Enzyme and Microbial Technology, 19, 529-537. http://dx.doi.org/10.1016/S0141-0229(96)00070-1

[27] FAO (1985) Guidelines: Land Evaluation for Irrigated Agriculture. Soils Bulletin 55, Food and Agriculture Organization of the United Nations, Rome.

[28] Singh, A., Sharma, R.K., Agrawal, M. and Marshall, F.M. (2010) Risk Assessment of Heavy Metal Toxicity through Contaminated Vegetables from Wastewater Irrigated Areas in Varanasi, India. Tropical Ecology, 51, 375-387. 
[29] Singh, O.V., Labana, S., Pandey, G., Budhirajaand, R. and Jain, R.K. (2003) Phytoremediation: An Overview of Metallic Ion Decontamination from Soil. Applied Microbiology and Biotechnology, 61, 405-412. http://dx.doi.org/10.1007/s00253-003-1244-4

[30] Magnuson, M.L., Ketty, C.A. and Kelty, K.C. (200l) Trace Metal Loading on Water-Borne Soil and Dust Particles Characterized through the Use of Spilt-Flow Thin-Cell Fractionation. Analytical Chemistry, 73, 3492-3496. http://dx.doi.org/10.1021/ac0015321

[31] Di Serio, M.G., Lanza, B., Mucciarella, M.R., Russi, F., Iannucci, E., Marfisi, P. and Madeo, A. (2008) Effects of Olive Mill Wastewater Spreading on the Physico-Chemical and Microbiological Characteristics of Soil. International Biodeterioration \& Biodegradation, 62, 403-407. http://dx.doi.org/10.1016/j.ibiod.2008.03.006

[32] Rattan, R.K., Datta, S.P., Chhonkar, P.K., Suribabu, K. and Singh, A.K. (2005) Long-Term Impact of Irrigation with Waste Water Effluents on Heavy Metal Content in Soils, Crops and Groundwater-A Case Study. Agriculture, Ecosystems and Environment, 109, 310-322. http://dx.doi.org/10.1016/j.agee.2005.02.025

[33] Ghosh, A.K., Bhatt, M.A. and Agrawal, H.P. (2012) Effect of Long-Term Application of Treated Sewage Water on Heavy Metal Accumulation in Vegetables Grown in Northern India. Environmental Monitoring and Assessment, 184, 1025-1036. http://dx.doi.org/10.1007/s10661-011-2018-6

[34] Chopra, A.K. and Pathak, C. (2013) Enrichment and Translocation of Heavy Metals in Soil and Spinacea oleracea Grown in Sugar Mill Effluent Irrigated Soil. Sugar Tech, 15, 77-83. http://dx.doi.org/10.1007/s12355-012-0194-5

[35] Kisku, G.C., Barman, S.C. and Bhargava, S.K. (2000) Contamination of Soil and Plants with Potentially Toxic Elements Irrigated with Mixed Industrial Effluent and Its Impact on the Environment. Water, Air, and Soil Pollution, 120, 121-137. http://dx.doi.org/10.1023/A:1005202304584

[36] Gupta, S., Nayek, S., Saha, R.N. and Satpati, S. (2008) Assessment of Heavy Metal Accumulation in Macrophyte, Agricultural Soil, and Crop Plants Adjacent to Discharge Zone of Sponge Iron Factory. Environmental Geology, 55, 731-739. http://dx.doi.org/10.1007/s00254-007-1025-y

[37] Marschner, H. (1986) Mineral Nutrition of Higher Plants. Academic Press, London.

[38] Kawatra, B.L. and Bakhetia, P. (2008) Consumption of Heavy Metal and Minerals by Adult Women through Food in Sewage and Tube Well Irrigated Area around Ludhiana City (Punjab, India). Journal of Human Ecology, 23, 351-354.

[39] Raj, B.G., Patnaik, M.C., Babu, S.P., Kalakumar, B., Singh, M.V. and Shylaja, J. (2006) Heavy Metal Contaminants in Water-Soil-Plant Animal Continuum Due to Pollution of Musi River around Hyderabad in India. Indian Journal of Animal Sciences, 76, 131-133.

[40] Singh, J., Upadhyay, S.K., Pathak, R.K. and Gupta, V. (2011) Accumulation of Heavy Metals in Soil and Paddy Crop (Oryza sativa), Irrigated with Water of Ramgarh Lake, Gorakhpur, UP, India. Toxicological and Environmental Chemistry, 93, 462-473. http://dx.doi.org/10.1080/02772248.2010.546559

[41] Rakesh Sharma, M.S. and Raju, N.S. (2013) Correlation of Heavy Metal Contamination with Soil Properties of Industrial Areas of Mysore, Karnataka, India by Cluster Analysis. International Research Journal of Environment Sciences, 2, 22-27.

[42] Barman, S.C., Sahu, R.K., Bhargava, S.K. and Chaterjee, C. (2000) Distribution of Heavy Metals in Wheat, Mustard and Weed Grown in Field Irrigated with Industrial Effluents. Bulletin of Environmental Contamination and Toxicology, 64, 489-496. http://dx.doi.org/10.1007/s001280000030 